\title{
Gender Differences in Gifted Elementary Students' Decision-Making about Renewable Energy: Social Relationships, Values, and Authority (RTP)
}

\section{Prof. Younkyeong Nam, Pusan National University}

Dr. Younkyeong Nam is an Associate Professor at Pusan National University in Busan, South Korea. Her research focuses on science and engineering integration in secondary science classrooms and environmental education in STEM. Dr. Younkyeong Nam is interested in designing engineering design-based science instruction that is more suitable for the educational context of South Korea. She is also interested in developing frameworks for designing and assessing STEM lessons to support K-12 science teachers.

\section{Dr. JinA Yoon, Pusan National University \\ Dr. Jeanna Wieselmann, Southern Methodist University}

Dr. Jeanna R. Wieselmann is a Research Assistant Professor at Southern Methodist University in Dallas, TX. Her research focuses on gender equity in STEM and maintaining elementary girls' interest in STEM through both in-school and out-of-school experiences. Dr. Wieselmann's research has explored student participation patterns in small group STEM activities. She is interested in STEM schools, integrated STEM curriculum development, and teacher professional development to support gender-equitable teaching practices. 


\title{
Gender Differences in Gifted Elementary Students’ Decision-Making about Renewable Energy: Social Relationships, Values, and Authority (RTP)
}

\begin{abstract}
This study examines how gender affected gifted elementary students' engineering-based argumentative practices and decision-making processes as they selected renewable energy sources to support South Korea's future. Twenty-one gifted elementary science students participated in four steps of the Jigsaw group discussion process: 1) single-gender group discussion before information was given, 2) single-gender group discussion after information was given, 3) mixedgender group discussion as a format of expert group discussion, and 4) original single-gender group discussion. Videotaped group discussions and student worksheets were the primary data sources. Students' argumentative practices were investigated in two aspects: social negotiation patterns and reasoning. The social negotiation patterns of students' argumentative practice were analyzed using an analytic framework adapted from Toulmin's model of argument structure, and the collaborative reasoning patterns of students' argumentative practice were analyzed based on Walton's reasoning scheme. Then their decision-making process was analyzed using an analytical framework developed by the authors. Social negotiation pattern results show that girls' social negotiation was more affected by gender grouping (single or mixed) than boys. However, there was no significant gender difference in terms of collaborative reasoning. We identified critical factors that affected students' final decisions in each unit of discourse analysis. Girls' engineering decisions were safety-oriented, so they prioritized energy options with "no known disadvantages" even if other options had known advantages. In contrast, boys selected an option if they felt that they had collected sufficient evidence to reach consensus and did not select an option if it included economic disadvantages or technological limitations.
\end{abstract}

\section{Introduction}

Argumentation plays a key role in engineering. For example, in a study of argumentation across the undergraduate curriculum, Wolfe [1] found that all of the engineering assignments included in the analysis required argumentation. Within the K-12 context, engaging in argument from evidence is one of the key science and engineering practices included in A Framework for K-12 Science Education [2] The Framework compares scientific argumentation to engineering argumentation, noting that scientific argumentation focuses on reaching the best explanation of a natural phenomenon; in contrast, engineering argumentation focuses on finding the best possible solution to a problem. Within engineering education, the term evidence-based reasoning is sometimes used to further distinguish the engineering practice from the science practice [3]. As 
engineers make decisions, they must use evidence to make decisions among competing design ideas.

Recently, socio-scientific issues (SSI) have received increased attention from many science and engineering educators, as it provides a meaningful learning opportunity to improve students' argumentation skills [4] - [7]. In the SSI environment, students can formulate positions, negotiate diverse ideas, and make decisions about important issues directly related to their everyday life [8]. The problems in SSI contexts are "more open-ended, debatable, complex, or ill-structured" [9, p.140] than the general scientific hypothesis in the laboratory. In this kind of environment, students are required to apply their epistemic understanding of argument (i.e., what counts as good evidence, what counts as a good claim) to debate, reach a consensus, or make decisions [10] - [12].

Sadler [6] proposed that students' epistemic practice in SSI are understood through both argumentation and informal reasoning [6], [13]. Based on an intensive literature review, Sadler [6] concluded that it is hard to assess the quality of student argumentation only by logical reasoning because in SSI contexts, everyday life experiences, moral and ethical beliefs, values, and culture affect students' argumentation practices. Duschl also points out that student argumentation in SSI is a reasoning strategy that involves the general reasoning domain of informal logic as well as critical thinking [10].

In most recent research concerning argumentation, Toulmin's model [14] was adopted as a useful tool to understand logical reasoning of argumentation. However, Toulmin's model is not sufficient to understand student arguments in SSI contexts. Researchers criticize Toulmin's model, pointing out that it is not suitable to analyze informal reasoning [15]. They argue that Toulmin's model is more useful for understanding formal structures of discourse like "monologue" rather than "dialogue" between people because it involves a back-and-forth series of reasoning [16]. Toulmin's model can show the structure of an argument but not the logical properties and detailed context behind the discourse [15]. To understand students' arguments in a more nuanced manner, researchers suggest using Walton's reasoning scheme [17] that is partially based on Toulmin's model but more nuanced on different types of reasoning [15], [18]. In his seminal book Argumentation Schemes for Presumptive Reasoning, Walton [17] characterizes 24 schemes of reasoning based on his previous work.

Even if we can consider Walton's model to understand student reasoning in different dialogue types that shape discourse (e.g., debate, reaching a consensus, persuasive dialogue), it is not enough to capture how students' interests, hidden assumptions, and shared cultural norms affect their argumentation. Sadler argues that, "even personal interest and investment in an SSI could improve argumentation related to that issue” [6, p. 519]. This echoes Sandoval and Millwood's idea that students' epistemological beliefs are affected by their own epistemic practice of making and evaluating knowledge claims [19]. In other words, students' contexts such as place they live 
and the cultural background in which they could build their own argument could affect their epistemological belief of what counts as a good claim and warrant.

In this study, we consider gender as one of the student factors that could shape students' discourse and epistemological beliefs. Studies show that boys and girls may have different assumptions about how to support or challenge others' claims. In teamwork contexts, girls are often less competitive but more relational and cooperative than boys and tend to maintain intimacy, share, and monitor each other's emotions [20] - [22]. Among undergraduate engineering students, women in female-majority groups felt less anxious and participated more in group discussions than those women in groups with more men or an equal number of men and women [23]. In contrast to monological approaches often taken by men, women's communication tends to be more interactive [24], with girls asking more probing questions than boys [25].

Building on these considerations, the primary objective of this study was to examine how gender affects students' decision-making process in an engineering-based SSI context related to renewable energy. Duschl suggested that we need to move beyond structured dialogue toward a framework that reflects how evidence is constructed and supported by reasoning [10]. To understand how a student's context (gender) shapes their reasoning and decision-making, students' argumentative practices were investigated in three aspects: (1) social negotiation patterns, (2) reasoning scheme, and (3) critical factors for making a final decision. First, the social negotiation patterns of students' argumentative practice were analyzed using an analytic framework adapted from Toulmin's model of argument structure [14], and the reasoning patterns of students' argumentative practice were analyzed based on Walton's reasoning scheme [17]. Then the critical factors for making a final decision were analyzed using an analytical scheme developed by the authors.

\section{Methodology}

This study utilized a qualitative research method grounded in a constructivist epistemology [26] to understand gifted elementary students' argumentative practices (social negotiation and reasoning, and critical factors for final decision) affected by gender.

Context. The engineering-based SSI debate activity was purposefully designed to engage participating students in a rich and meaningful decision-making process by providing a multifaceted context of selecting renewable energy for the future society of South Korea based on economic, environmental, industrial, and scientific information about different renewable energy sources. The SSI activity had four phases of a Jigsaw group decision-making process based on students' knowledge of renewable energy. Instructional design of each phase was developed by modifying components of Model Eliciting Activity (MEA) [27]: newspaper article, readiness question, problem statement, process of sharing solutions. In each phase, students were asked to recommend, in order of importance, five renewable energy sources for political decisions while considering the benefits and consequences of choosing each renewable energy source. We also 
grouped students in single-gender or mixed-gender groups for the research question. The specific instructional process of the activities and objectives of each phase are described below.

Phase one. In the beginning of phase one, students learn what renewable energy is and different types of renewable energy. After this instruction, students read a newspaper article about international concerns about renewable energy and answer questions about the article content on worksheets. After that, students individually read a letter from President Moon of South Korea asking them to choose five renewable energy sources that they think are most efficient and suitable for the economic and geological context of South Korea. Students individually work to rank five choices for renewable energy and write reasons including important values they considered for their choice. Then they are grouped in a single-gender group (boys or girls) and asked to discuss their individual ideas to move toward a collective decision about what kind of renewable energy they will recommend as a group.

Phase two. In phase two, more information about renewable energy is given to the students in a single-gender group. They individually read the information and discuss their decisions in light of the new information, considering whether to keep or modify their decision from phase one. This phase provides students with more information and allows them to examine how knowledge about the topic changes their discussion in the decision-making process. The information includes news articles and reports written from four different perspectives (scientist, industry, NGOs for Environmental protection, and local citizen community).

Phase three. Students in a single-gender group choose one of four expert roles (scientist, industry, NGOs for Environmental protection, and local citizen community) and move to the jigsaw expert group to discuss the pros and cons of each renewable energy and reformulate their decisions for ranking the five renewable energy sources in recommendation to the government.

Phase four. Students come back to their original group (single-gender group) and reach group consensus for their final recommendation letter to President Moon. In this discussion, students can decide whether to keep or change their original decision, but they must write a rationale for their decision and describe what kinds of values they considered most in their decision.

Participants. Twenty-one 5th and 6th grade students participated in the activity (9 girls and 12 boys). They were all enrolled in a gifted science education program in a national university in South Korea. They passed very competitive and rigorous tests to enter the program (classroom teachers' recommendation, personal statement, written exam of creative problem solving in both mathematics and science, science writing test, and observation of collaboration and communication skills in group problem solving context).

Data collection. Participant worksheets during the instruction and discussion were collected and the duration of the activity was videotaped. The participants' arguments during the decisionmaking discussion in each phase (single-gender groups in first, second, and fourth discussion and 
third expert group discussion in mixed-gender groups) were also voice recorded and transcribed as the primary data source for this study. Transcript excerpts were translated into English for the purposes of this paper.

Data analysis. The data analysis in this study was built on our previous study [28] in which we proposed two dimensions of argumentation in school science: social negotiation and epistemic understanding of argument. In this study, we considered gender as an important factor that affects students' decision-making processes. Thus, the ultimate goal of the data analysis was to examine the participants' discussion in three aspects: social negotiation pattern, epistemic understanding of argument (collaborative reasoning), and critical factors for final decision-making during the SSI decision-making process. To reach the goal, the analysis of group discussion involved two complementary analytical approaches: (1) constant comparative methods [29] and (2) the enumerative approach [30]. First, all transcriptions (in Korean) were broken into individual utterances as the unit of analysis. Each utterance represented an idea or opinion contributed to the discussion. An individual's verbal turn could consist of one or multiple utterances depending on how many ideas were included in one segment of verbal communication. Three separate sets of coding schemes were developed and applied to the same data set to analyze social negotiation patterns, reasoning (epistemic understanding of argument), and critical factors for final decisions. A detailed description of each analysis process is provided below.

Analyzing social negotiation patterns. To assess participants' argumentation structure as a social negotiation pattern, we developed an initial set of codes to capture how they constructed and critiqued each other's ideas. First, a coding scheme was developed using open coding [29]; this scheme was also informed by previous studies [28], [31], [32]. Emerging codes were then categorized based on the function of similarities and differences for social negotiation. Eight codes subsequently emerged: clarify, support, challenge, recognize, propose, defend, reject, respond, and facilitate. Compared to our previous work, we added the facilitation code that includes four subcodes: facilitation for smooth flow of communication, checking and exchange of information, repeating or rephrasing someone's idea (words) to help others to understand it, and summarizing or elaborating on another's idea. The result of social negotiation pattern analysis shows that nearly half of the discourse belonged to the facilitation due to the type of discourse, namely decisionmaking [15]. Table 1 presents the final codes and examples of each code. Based on the coding scheme, participants' discourse was analyzed by at least three researchers to examine the reliability and validity of the analysis methods. We counted the frequency of the participants' discourse type based on the coding scheme to discover patterns in their social negotiation. 
Table 1. Social negotiation coding scheme (modified from [28])

\begin{tabular}{|c|c|}
\hline Coding (Definition) & Coding Example \\
\hline $\begin{array}{l}\text { 1. Clarify (Clf.): Give a clear explanation } \\
\text { about a situation or example to clarify the } \\
\text { individual's idea }\end{array}$ & $\begin{array}{l}\text { Piezoelectric power. It puts piezo on the road, but piezo doesn't cost so much. } \\
\text { It looks like our lab kit, but there are piezoelectric kits. If you press that, it'll } \\
\text { light up. No, it's not that expensive. it's not like that? }\end{array}$ \\
\hline $\begin{array}{l}\text { 2. Support (Spt.) : Any response used by an } \\
\text { individual to accept or agree with someone } \\
\text { else's ideas }\end{array}$ & $\begin{array}{l}\text { I think the sun will be fine too. Because solar power needs to be supported by } \\
\text { the government to do this. But if it is installed on the roof, it will be supported } \\
\text { by the government and opinions of local residents, so of course, it can be used } \\
\text { in our country and residents will be good? }\end{array}$ \\
\hline $\begin{array}{l}\text { 3. Challenge (Clg.): Any response used by } \\
\text { an individual to critique others' ideas or } \\
\text { arguments }\end{array}$ & $\begin{array}{l}\text { Now, solar power needs a large land first. How do we fill this large land, and } \\
\text { when we think about our position as an environmental organization ... How } \\
\text { can we install this in a way that does not destroy the environment? }\end{array}$ \\
\hline $\begin{array}{l}\text { 4. Recognize (Rcg.): Acknowledge and } \\
\text { realize the existence of factors and } \\
\text { variables that could affect the current } \\
\text { situation or problem }\end{array}$ & $\begin{array}{l}\text { But we have to think about what to consider when we set the energy. Shouldn't } \\
\text { we think about our role as an environmental organization? }\end{array}$ \\
\hline $\begin{array}{l}\text { 5. Propose (Prp.) : Give a new idea, } \\
\text { assumption, or explanation to solve a given } \\
\text { situational problem }\end{array}$ & $\begin{array}{l}\text { I think the third energy is wind power. If global warming gets worse, the } \\
\text { amount of water evaporated from the sea will increase. If that happens, the } \\
\text { temperature difference between the air will increase and the wind will blow a } \\
\text { lot. How is wind power? }\end{array}$ \\
\hline $\begin{array}{l}\text { 6. Defend (Dfd.): Provide an alternative } \\
\text { idea which is different or conflicts with the } \\
\text { individual's ideas; any response used by an } \\
\text { individual to persuade others about his/her } \\
\text { ideas }\end{array}$ & $\begin{array}{l}\text { Nuclear power is a big risk, but if the accident rate is lower than a plane } \\
\text { accident, and if it is managed well, it is not a big problem. As long as there } \\
\text { are no problems with aging nuclear power plants, there is no big problem. } \\
\text { And the best thing about nuclear power is that now it's nuclear power but it } \\
\text { can be powered by nuclear fusion power. }\end{array}$ \\
\hline $\begin{array}{l}\text { 7. Reject (Rjt.): Any response used by an } \\
\text { individual to disagree with all or part of the } \\
\text { speaker's ideas }\end{array}$ & $\begin{array}{l}\text { When geothermal power is generated, an earthquake occurs. The people are } \\
\text { anxious. What will happen then? }\end{array}$ \\
\hline $\begin{array}{l}\text { 8. Respond (Rsp.): Give a relevant and } \\
\text { meaningful answer to someone's question }\end{array}$ & $\begin{array}{l}\text { What's the good thing if you choose this fusion technology, now Saudi Arabia } \\
\text { is rich with oil? If we develop fusion technology earlier than other countries, } \\
\text { we can sell it to other countries. }\end{array}$ \\
\hline $\begin{array}{l}\text { 9. Facilitate (Fac.) : Facilitate the flow of } \\
\text { communication or exchange of information }\end{array}$ & $\begin{array}{l}\text { Well... Tidal and solar power coming, can anyone tell me why solar power } \\
\text { is better? That's a good reason for thinking that solar power is good. }\end{array}$ \\
\hline
\end{tabular}

Analyzing collaborative engineering reasoning patterns. To assess each group's collaborative engineering reasoning pattern, we adopted Walton's reasoning scheme [17] for an initial analysis. Walton's reasoning scheme is useful to understand specific reasoning patterns in different discourse types [15], and it is more often used in the context of science than other disciplines [33]. 
Depending on the context of the discourse, the number of reasoning schemes are different. In this study, participant discourse was dependent on the discipline of science, and the type of discourse was decision-making in which students collaboratively made decisions. Walton's reasoning schemes were identified: Expert opinion, Consequences, Popularity, Position to know, Cause to effect, Correlation, Bias, Analogy, and Commitment. We also analyzed Critical Questions students posed during the discussion to assess the quality of the discourse. Table 2 presents the final coding scheme and an explanation of the criteria for each code with examples. To examine the inter-rater reliability of the coding, the three researchers independently coded the transcripts. The initial percentage of agreement for social negotiation was $92 \%$ and for reasoning patterns was $86 \%$. Any disagreements were discussed and refined until an agreement was reached, and the initial coding was adjusted accordingly.

Table 2. Walton's reasoning schemes and examples

\begin{tabular}{|c|c|c|}
\hline Schemes & Modified Criteria & Coding examples \\
\hline $\begin{array}{l}\text { Critical Question } \\
\text { (C) }\end{array}$ & $\begin{array}{l}\text { A series of important questions that require } \\
\text { students to determine whether they are used } \\
\text { systematically and appropriately in each } \\
\text { argument system }\end{array}$ & $\begin{array}{l}\text { It is not good if it is environmental pollution. However, } \\
\text { environmental pollution does not mean that you cannot } \\
\text { use it unconditionally. Is oil and coal still in use? }\end{array}$ \\
\hline $\begin{array}{l}\text { Expert Opinion } \\
\text { (Exp) }\end{array}$ & $\begin{array}{l}\text { Mentioning given information, expert } \\
\text { sources to support personal reasoning or } \\
\text { perspectives }\end{array}$ & $\begin{array}{l}\text { The teacher said that wind power generation is difficult } \\
\text { to set up if it opposes noise problems or residents install } \\
\text { it. }\end{array}$ \\
\hline $\begin{array}{l}\text { Consequences } \\
\text { (Con) }\end{array}$ & $\begin{array}{l}\text { Practical reasoning in which a policy or } \\
\text { action is supported/rejected on the grounds } \\
\text { that the consequences will be good/bad. A } \\
\text { statement about the value of the conclusion } \\
\text { without any expressed concerns for the } \\
\text { properties nor the events that comprise the } \\
\text { full argument }\end{array}$ & $\begin{array}{l}\text { It's the solar power that I chose, because the sunlight is } \\
\text { infinite, and I've chosen it because it can be received } \\
\text { anywhere on Earth. }\end{array}$ \\
\hline $\begin{array}{l}\text { Popularity } \\
\text { (Pop) }\end{array}$ & $\begin{array}{l}\text { Members of the discussion group overtly or } \\
\text { implicitly accept a notion as a socially and } \\
\text { culturally embedded norm and practice. }\end{array}$ & $\begin{array}{l}\text { We should focus on stability and pollution. That's why } \\
\text { people don't like dangerous things. }\end{array}$ \\
\hline $\begin{array}{l}\text { Position to know } \\
\text { (Po) }\end{array}$ & $\begin{array}{l}\text { When there is not enough information to } \\
\text { judge and additional information is required, } \\
\text { it is assumed that A knows or has access to } \\
\text { information that it does not have. }\end{array}$ & $\begin{array}{l}\text { You said you use solar energy in space to get the best } \\
\text { efficiency. What are the costs and benefits? A: Actually, } \\
\text { my friend chose it by telling me that it was possible, and } \\
\text { I heard it was possible in the very distant future. }\end{array}$ \\
\hline $\begin{array}{l}\text { Cause to effect } \\
\text { (Ca:) }\end{array}$ & $\begin{array}{l}\text { Reference to premises that are causally } \\
\text { linked to a noncontroversial effect. effect is } \\
\text { an observable outcome, with need for testing. }\end{array}$ & $\begin{array}{l}\text { I think the environmental value should be included in the } \\
\text { core value. Because environmental pollution is related to } \\
\text { greenhouse gas emissions. }\end{array}$ \\
\hline $\begin{array}{l}\text { Correlation } \\
\text { to cause(Co) }\end{array}$ & $\begin{array}{l}\text { Inferring the causal relationship between two } \\
\text { events on the premise that describes the } \\
\text { correlation between two events }\end{array}$ & $\begin{array}{l}\text { Future energy must be safe to continue to use and } \\
\text { develop. If it is not safe, money is consumed. So, it must } \\
\text { be safe so that the energy source can be continuously } \\
\text { developed and used. }\end{array}$ \\
\hline Bias & $\begin{array}{l}\text { Students brought statements with skepticism } \\
\text { and doubt the credibility of others' } \\
\text { information or standpoints. Arguer (“a”) is } \\
\text { biased, so likely has not taken evidence on } \\
\text { both sides of issue into account. }\end{array}$ & $\begin{array}{l}\text { I think efficiency is important even if we pollute the } \\
\text { environment. Except for oil, the energy we choose is } \\
\text { efficient. }\end{array}$ \\
\hline
\end{tabular}




\begin{tabular}{l|l|l}
\hline $\begin{array}{l}\text { Analogy } \\
\text { (Anal) }\end{array}$ & $\begin{array}{l}\text { Referring to a case that is proffered to be } \\
\text { analogous to the topic being discussed. Used } \\
\text { to argue from one case that is said to be } \\
\text { similar to another. }\end{array}$ & $\begin{array}{l}\text { Is there a guarantee that the fuel cell will still be used } \\
\text { even in the future? Therefore, fuel cells are not used } \\
\text { much yet, so we cannot guarantee that they will be used } \\
\text { in the future. }\end{array}$ \\
\hline $\begin{array}{l}\text { Commitment } \\
\text { (com) }\end{array}$ & $\begin{array}{l}\text { Repeating or rephrasing the same position to } \\
\text { maintain a commitment to a particular idea or } \\
\text { action. }\end{array}$ & $\begin{array}{l}\text { First of all, the government should think about the } \\
\text { position of citizens, and because of the budget, I think I } \\
\text { should make an energy source that can get a lot of energy } \\
\text { and efficiency even if it costs a bit like a nuclear power } \\
\text { plant. }\end{array}$ \\
\hline $\begin{array}{l}\text { Inductive } \\
\text { (Ind) }\end{array}$ & $\begin{array}{l}\text { students' reasoning skill of applying general } \\
\text { ideas to a specific situation to use as } \\
\text { evidence to support their claim }\end{array}$ & $\begin{array}{l}\text { We've chosen renewable energy, low cost, low } \\
\text { technology maintenance costs, so the technology has } \\
\text { been proven. So I chose wind power because it was } \\
\text { reliable. }\end{array}$ \\
\hline $\begin{array}{l}\text { Deductive } \\
\text { (Ded) }\end{array}$ & $\begin{array}{l}\text { students' reasoning skills of generalizing } \\
\text { examples from a specific situation to a } \\
\text { broader context to use as evidence to support } \\
\text { their claim }\end{array}$ & $\begin{array}{l}\text { The reason why I chose solar power is that if global } \\
\text { warming gets worse, the earth will get hot. Even in the } \\
\text { case of wind, if global warming is getting worse, the } \\
\text { amount of water evaporating from the sea will increase. } \\
\text { If that happens, the temperature difference between the } \\
\text { air will increase and wind will be generated. }\end{array}$ \\
\hline $\begin{array}{l}\text { Argument from } \\
\text { example(exam) }\end{array}$ & $\begin{array}{l}\text { An example is used to support a } \\
\text { generalization }\end{array}$ & $\begin{array}{l}\text { I recently heard a study called "Star" succeeded in } \\
\text { keeping the temperature up to 100 million degrees for a } \\
\text { while. But it cost a lot of resources and money. }\end{array}$ \\
\hline
\end{tabular}

Analyzing critical factors for final decision-making. Compared to the previous analytic framework that assessed structure of social negotiation and collaborative reasoning in terms of the quality of argument, this framework was used to understand how gender-based social expectations affected students' engineering decision-making process for the topic. First, we carefully read each utterance and grouped it as a unit based on the main topic and content discussed. A useful unit we found was the chunk of discourse for ranking each renewable energy in relation to the others because it required students to collaboratively compare variables and complex contexts related to their choice. Emerging codes were then categorized based on the function of denials and acceptances for the final decision. As Table 3 presents, five codes subsequently emerged. In each chunk of discourse, first we carefully analyzed important factors that directly affected students' decisions by using different means. We drew concept map diagrams and used frequency analysis to understand the flow of students' ideas in dealing with variables and others students' suggestions or challenges. Table 3 presents the coding scheme that we developed to analyze critical factors that affect students' final decision-making and examples from the data analysis. 
Table 3. Critical factors for final decision-making

\begin{tabular}{|c|c|c|}
\hline $\begin{array}{l}\text { Decision } \\
\text { Factors }\end{array}$ & Sub-element & Example \\
\hline \multirow[b]{2}{*}{$\begin{array}{l}\text { 1. Obedience } \\
\text { to authority }\end{array}$} & $\begin{array}{l}\text { 1.1. Obedience to } \\
\text { authority (Expert) }\end{array}$ & $\begin{array}{l}\text { Decisions are made by expert opinions or data-driven arguments } \\
\text { that support and induce personal inference }\end{array}$ \\
\hline & $\begin{array}{l}\text { 1.2. Obedience to } \\
\text { authority (Peer) }\end{array}$ & $\begin{array}{l}\text { When no alternative is offered, or when opinions are not reached, } \\
\text { decisions are made by a strongly asserting member (leader). } \\
\text { Leaders lead decision-making within the group by succeeding } \\
\text { logically and illogically defending against claims and challenges. }\end{array}$ \\
\hline \multicolumn{2}{|c|}{ 2. Sufficient evidence for agreement } & $\begin{array}{l}\text { When consensus is reached by collecting opinions of members on } \\
\text { the basis of scientific evidence or sufficient information exchange } \\
\text { in the decision-making process }\end{array}$ \\
\hline \multirow{2}{*}{$\begin{array}{l}\text { 3. Moral/ } \\
\text { ethical value }\end{array}$} & $\begin{array}{l}\text { 3.1. Violation of } \\
\text { ethical/moral value }\end{array}$ & $\begin{array}{l}\text { In decision-making, ethical and moral values take precedence over } \\
\text { the recognition of various variables. Therefore, if violate ethical } \\
\text { and moral values are pointed out, they are excluded from the } \\
\text { decision }\end{array}$ \\
\hline & $\begin{array}{l}\text { 3.2. To support } \\
\text { ethical/moral value }\end{array}$ & $\begin{array}{l}\text { In decision-making, ethical and moral values take precedence over } \\
\text { the recognition of various variables. } \\
\text { (Environmental destruction, opposition from local residents, risks, } \\
\text { etc.) }\end{array}$ \\
\hline \multicolumn{2}{|c|}{ 4. Personal priorities } & $\begin{array}{l}\text { If there is internal consensus already in the decision-making } \\
\text { process or if it meets personal preferences, there is no objection to } \\
\text { the opinions presented and they are decided immediately without } \\
\text { discussion. }\end{array}$ \\
\hline \multirow{2}{*}{$\begin{array}{l}\text { 5. Disadvan } \\
\text {-tages }\end{array}$} & $\begin{array}{l}\text { 5.1. No known } \\
\text { disadvantages }\end{array}$ & $\begin{array}{l}\text { Although there are no particular advantages in the decision- } \\
\text { making process, cases with few disadvantages are selected (the } \\
\text { lack of accurate scientific knowledge and the difficulty of } \\
\text { predicting them make it difficult to discuss pros and cons) }\end{array}$ \\
\hline & $\begin{array}{l}\text { 5.2. Economic } \\
\text { disadvantage/ } \\
\text { Technological } \\
\text { limitation }\end{array}$ & $\begin{array}{l}\text { Among the various variables of decision-making, problems such } \\
\text { as economic benefits, cost, efficiency, technological limitations, } \\
\text { and risks are immediately excluded from the decision. }\end{array}$ \\
\hline
\end{tabular}

\section{Results}

Gender differences in social negotiation patterns. Students' social negotiation patterns were analyzed by single-gender groups and mixed-gender groups, and the comparison between the gender groups is presented in this section. In the activity, students engaged in the first, second, and fourth discussions as a single-gender group and the third discussion as mixed-gender group. Table 4 presents analysis results of students’ social negotiation patterns by gender. 
Table 4. Comparison of social negotiation patterns in single- and mixed-gender groups

\begin{tabular}{|c|c|c|c|c|c|c|}
\hline \multirow[t]{2}{*}{ Code } & \multirow{2}{*}{$\begin{array}{l}\text { Number of } \\
\text { utterance } \\
\text { (\%) in girls } \\
\text { only group } \\
\text { Number and } \\
\text { percentage } \\
\text { of utterance } \\
\text { in girls-only } \\
\text { group }\end{array}$} & \multirow[t]{2}{*}{$\begin{array}{c}\text { Number of } \\
\text { utterance (\%) } \\
\text { in boys only } \\
\text { group }\end{array}$} & $\begin{array}{c}\text { Number of } \\
\text { utterance (\%) of } \\
\text { girls in mixed } \\
\text { gender group }\end{array}$ & $\begin{array}{c}\text { Number of } \\
\text { utterance (\%) of } \\
\text { boys in mixed } \\
\text { gender group }\end{array}$ & \multirow{2}{*}{$\begin{array}{c}\text { Number of } \\
\text { utterance of } \\
\text { girls and } \\
\text { (percents in total } \\
\text { number of girl's } \\
\text { utterance) }\end{array}$} & \multirow{2}{*}{$\begin{array}{c}\text { Number of } \\
\text { utterance of } \\
\text { boys and } \\
\text { (percents in total } \\
\text { number of boy's } \\
\text { utterance) }\end{array}$} \\
\hline & & & \multicolumn{2}{|c|}{$\begin{array}{c}\text { Number of utterance (\%) in mixed } \\
\text { gender group }\end{array}$} & & \\
\hline \multirow{2}{*}{ - Reject } & \multirow[t]{2}{*}{44 (10) } & \multirow[t]{2}{*}{$42(7.7)$} & $23(4.3)$ & $28(5.2)$ & \multirow{2}{*}{$\begin{array}{c}23 \\
(18.9)\end{array}$} & \multirow{2}{*}{$\begin{array}{c}28 \\
(6.8)\end{array}$} \\
\hline & & & \multicolumn{2}{|c|}{$51(9.5)$} & & \\
\hline \multirow{2}{*}{ Respond } & \multirow[t]{2}{*}{$42(9.5)$} & \multirow[t]{2}{*}{$40(7.3)$} & $4(0.7)$ & $23(4.3)$ & \multirow{2}{*}{$\begin{array}{c}4 \\
(3.3)\end{array}$} & \multirow{2}{*}{$\begin{array}{c}23 \\
(5.6)\end{array}$} \\
\hline & & & \multicolumn{2}{|c|}{$27(5.0)$} & & \\
\hline \multirow{2}{*}{$\begin{array}{l}\text { Challenge } \\
\text { - }\end{array}$} & \multirow[t]{2}{*}{$42(9.5)$} & \multirow[t]{2}{*}{$100(18.2)$} & 21 (3.9) & $80(15.0)$ & \multirow{2}{*}{$\begin{array}{c}21 \\
(17.2)\end{array}$} & \multirow{2}{*}{$\begin{array}{c}80 \\
(19.4)\end{array}$} \\
\hline & & & \multicolumn{2}{|c|}{101 (18.9) } & & \\
\hline \multirow{2}{*}{ Clarify } & \multirow[t]{2}{*}{$24(5.5)$} & \multirow[t]{2}{*}{27 (4.9) } & $1(0.2)$ & 35 (6.5) & \multirow{2}{*}{$\begin{array}{c}1 \\
(0.8)\end{array}$} & \multirow{2}{*}{$\begin{array}{c}35 \\
(8.5)\end{array}$} \\
\hline & & & \multicolumn{2}{|c|}{$36(6.7)$} & & \\
\hline \multirow[t]{2}{*}{ Defend } & \multirow[t]{2}{*}{$34(7.7)$} & \multirow[t]{2}{*}{85 (15.5) } & $8(1.5)$ & 69 (12.9) & \multirow[t]{2}{*}{$\begin{array}{c}8 \\
(6.6)\end{array}$} & \multirow[t]{2}{*}{$\begin{array}{c}69 \\
(16.7)\end{array}$} \\
\hline & & & \multicolumn{2}{|c|}{77 (14.4) } & & \\
\hline Recognize & 29 (6.6) & $13(2.4)$ & $16(3.0)$ & $20(3.7)$ & $\begin{array}{c}16 \\
(13.1)\end{array}$ & $\begin{array}{c}20 \\
(4.8)\end{array}$ \\
\hline & & & & & & \\
\hline Propose & $121(27.5)$ & $172(31.4)$ & $25(4.7)$ & $107(20.0)$ & 25 & 107 \\
\hline & & & 132 & 4.7) & & \\
\hline Support & 104 (23.6) & $69(12.6)$ & $24(4.5)$ & $51(9.5)$ & 24 & 51 \\
\hline & & & & 4.0) & & \\
\hline Total & 440 (100) & $548(100)$ & 122 (22.8) & $413(77.2)$ & $122(100)$ & $413(100)$ \\
\hline
\end{tabular}

* The number in Table 4 is the number of utterance frequencies, and the number of parentheses(\%) indicates the ratio of overall contrast.

First, the frequency of utterances used in both boys' and girls' groups was similar in the categories of 'reject', 'respond', 'clarify', 'recognize', and 'propose' in a single-gender group. However in the categories of 'challenge' and 'defend', the percentage of utterances in all-boys groups was two times higher than in all-girl groups, whereas all-girl group utterances in the category of 'support' 
were twice as many as all-boy groups. This result implies that when girls and boys work in singlegender groups, their social negotiation pattern might be different, with girls using more supportive discourse in communication than boys, and boys' social interaction characterized by challenging and defending types of interaction. This result echoes other studies' findings about gender differences in discussion patterns in science classrooms.

Interestingly, the social negotiation pattern in single-gender groups changed in mixed-gender groups. The difference between single- and mixed-gender groups is much more notable in girls' groups (Figure 1). First, compared to single-gender groups, girls talk less in mixed-gender groups, whereas the number of utterances of boys did not change much by the type of grouping.

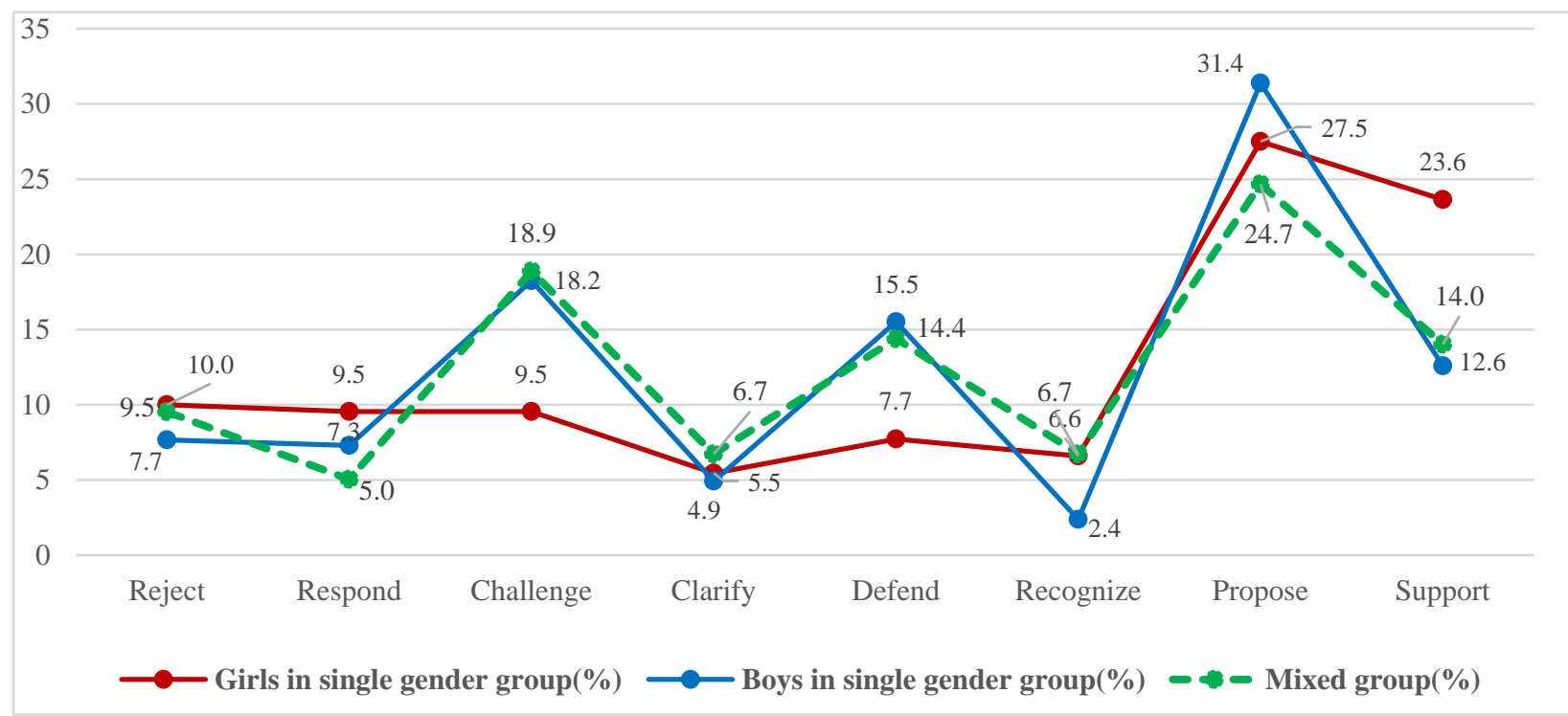

Figure 1. Comparison of social negotiation patterns in single- and mixed-gender group discussions

More importantly, girls' social negotiation patterns in mixed-gender groups were different than patterns within girl-only groups, whereas boys' social negotiation patterns were similar in both single-gender mixed-gender groups (Figure 2 \& 3). In mixed-gender groups, girls used more 'reject', 'challenge', and 'propose' type utterances than in single-gender groups. 


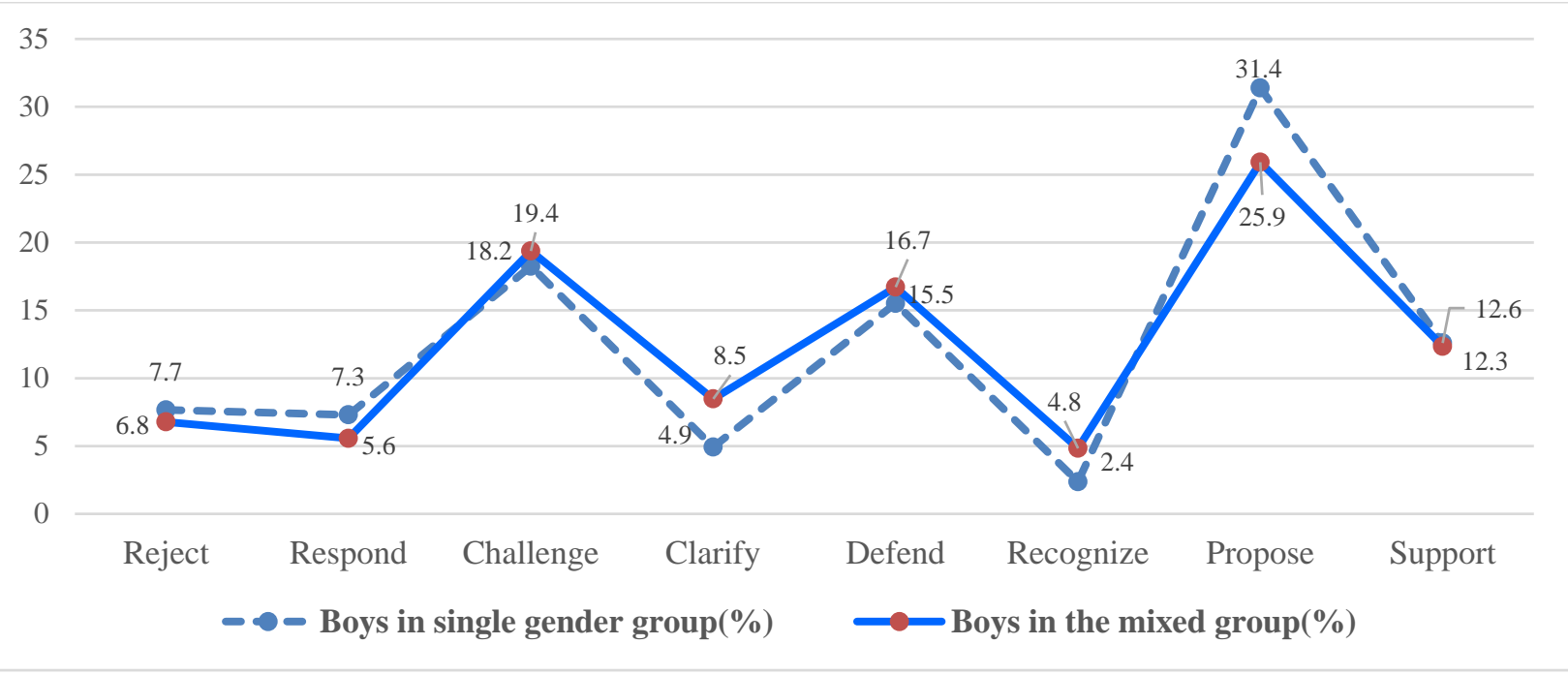

Figure 2. Differences in boys' social negotiation patterns in single- and mixed-gender groups

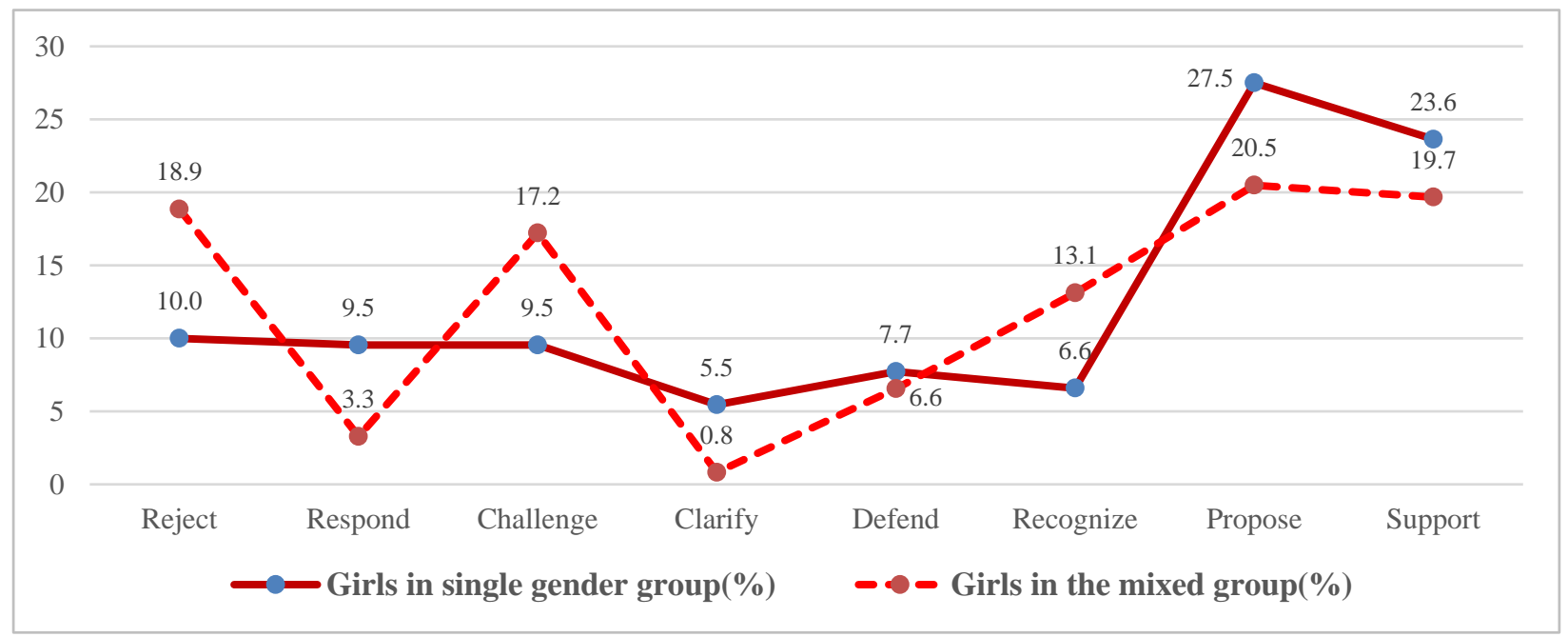

Figure 3. Differences in boys' social negotiation patterns in single- and mixed-gender groups

On average, the number of girls' utterances is $13 \%$ less than boys' in single-gender groups. However, in mixed-gender groups, the percentage of girls' utterances is only $22.8 \%$ of all the utterances, which is three times less than the percentage of boys' utterances. Specifically, in mixedgender groups, boys: proposed claims four times more, defended ideas eight times more, and challenged other ideas three times more than girls (Figure 4). This result implies that gender grouping itself could affect girls' argumentative practices in the decision-making process. 


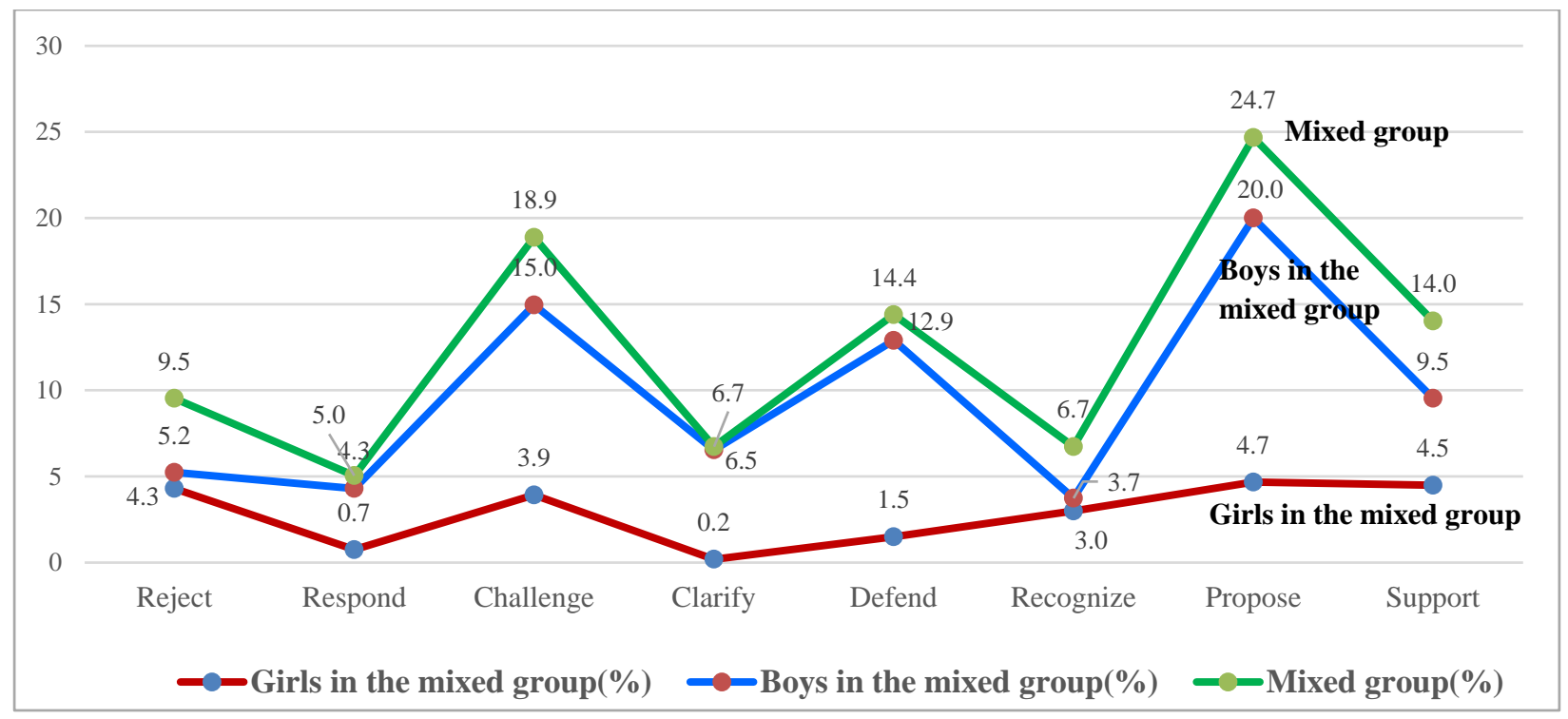

Figure 4. Proportion of girls’ and boys’ utterances in the mixed-gender group

Collaborative engineering reasoning in decision-making. In this section, we present the result of students' collaborative reasoning in the decision-making process by utilizing Walton's reasoning model. Table 5 presents students' reasoning patterns in single and mixed-gender groups.

Table 5. Collaborative engineering reasoning in single and mixed-gender group

\begin{tabular}{|c|c|c|c|c|c|c|c|c|c|c|}
\hline \multirow[t]{2}{*}{ Scheme } & \multicolumn{2}{|c|}{$\begin{array}{l}\text { First group } \\
\text { discussion }\end{array}$} & \multicolumn{2}{|c|}{$\begin{array}{l}\text { Second group } \\
\text { discussion }\end{array}$} & \multicolumn{2}{|c|}{$\begin{array}{c}\text { Final group } \\
\text { discussion }\end{array}$} & \multicolumn{2}{|c|}{$\begin{array}{l}\text { Single-gender } \\
\text { group average }\end{array}$} & \multicolumn{2}{|c|}{$\begin{array}{c}\text { Expert } \\
\text { discussion }\end{array}$} \\
\hline & $\begin{array}{l}\text { Girls } \\
\text { group }\end{array}$ & $\begin{array}{l}\text { Boys } \\
\text { group }\end{array}$ & $\begin{array}{l}\text { Girls } \\
\text { group }\end{array}$ & $\begin{array}{l}\text { Boys } \\
\text { group }\end{array}$ & $\begin{array}{l}\text { Girls } \\
\text { group }\end{array}$ & $\begin{array}{l}\text { Boys } \\
\text { group }\end{array}$ & $\begin{array}{c}\text { Girls } \\
\text { group (\%) }\end{array}$ & $\begin{array}{c}\text { Boys } \\
\text { group (\%) }\end{array}$ & $\begin{array}{c}\text { Girls } \\
\text { group (\%) }\end{array}$ & $\begin{array}{c}\text { Boys } \\
\text { group (\%) }\end{array}$ \\
\hline Critical Question & 6 & 13 & 3 & 7 & 2 & 6 & $11(7.1)$ & $26(11.2)$ & 7 (11.7) & $14(8.8)$ \\
\hline Expert Opinion & 5 & 4 & 17 & 11 & 2 & 3 & $24(15.4)$ & $18(7.8)$ & 10 (16.7) & $15(9.4)$ \\
\hline Consequences & 26 & 48 & 28 & 46 & 19 & 33 & $73(46.8)$ & $127(54.7)$ & 25 (41.7) & $72(45.3)$ \\
\hline Popularity & 5 & 1 & 1 & 0 & 1 & 1 & $7(4.5)$ & $2(0.9)$ & $0(0.0)$ & $0(0.0)$ \\
\hline Position to know & 0 & 0 & 0 & 0 & 0 & 2 & $0(0.0)$ & $2(0.9)$ & $0(0.0)$ & $0(0.0)$ \\
\hline Cause to effect & 1 & 4 & 1 & 0 & 1 & 2 & $3(1.9)$ & $6(2.6)$ & $0(0.0)$ & $7(4.4)$ \\
\hline Correlation & 5 & 11 & 2 & 0 & 4 & 4 & $11(7.1)$ & $15(6.5)$ & $1(1.7)$ & $5(3.1)$ \\
\hline Bias & 2 & 1 & 1 & 3 & 0 & 1 & $3(1.9)$ & $5(2.2)$ & $0(0.0)$ & $4(2.5)$ \\
\hline Analogy & 2 & 4 & 2 & 2 & 1 & 1 & $5(3.2)$ & $7(3.0)$ & $1(1.7)$ & $9(5.7)$ \\
\hline Commitment & 2 & 0 & 0 & 0 & 9 & 14 & $11(7.1)$ & $14(6.0)$ & 13 (21.7) & $29(18.2)$ \\
\hline
\end{tabular}




\begin{tabular}{l|cc|cc|cc|cc|cc} 
Inductive & 2 & 6 & 0 & 0 & 1 & 1 & $3(1.9)$ & $7(3.0)$ & $1(1.7)$ & $0(0.0)$ \\
\hline Deductive & 3 & 1 & 0 & 0 & 1 & 0 & $4(2.6)$ & $1(0.4)$ & $2(3.3)$ & $0(0.0)$ \\
\hline Example & 0 & 1 & 0 & 1 & 1 & 0 & $1(0.6)$ & $2(1.9)$ & $0(0.0)$ & $4(2.5)$ \\
\hline Total & 59 & 94 & 55 & 70 & 42 & 68 & $156(100)$ & $232(100)$ & $60(100)$ & $159(100)$ \\
& & & & & & & & & & \\
\hline
\end{tabular}

First, in both girls' and boys' group discussions, the code of 'Consequences' appears most frequently (See Figure 5), meaning that students reasoned about consequences of their decision more frequently than they used other reasoning patterns. The only notable difference between gender in reasoning codes is that girls used more 'Expert opinion' reasoning than boys. This pattern was similar in both single-gender and mixed-gender groups.

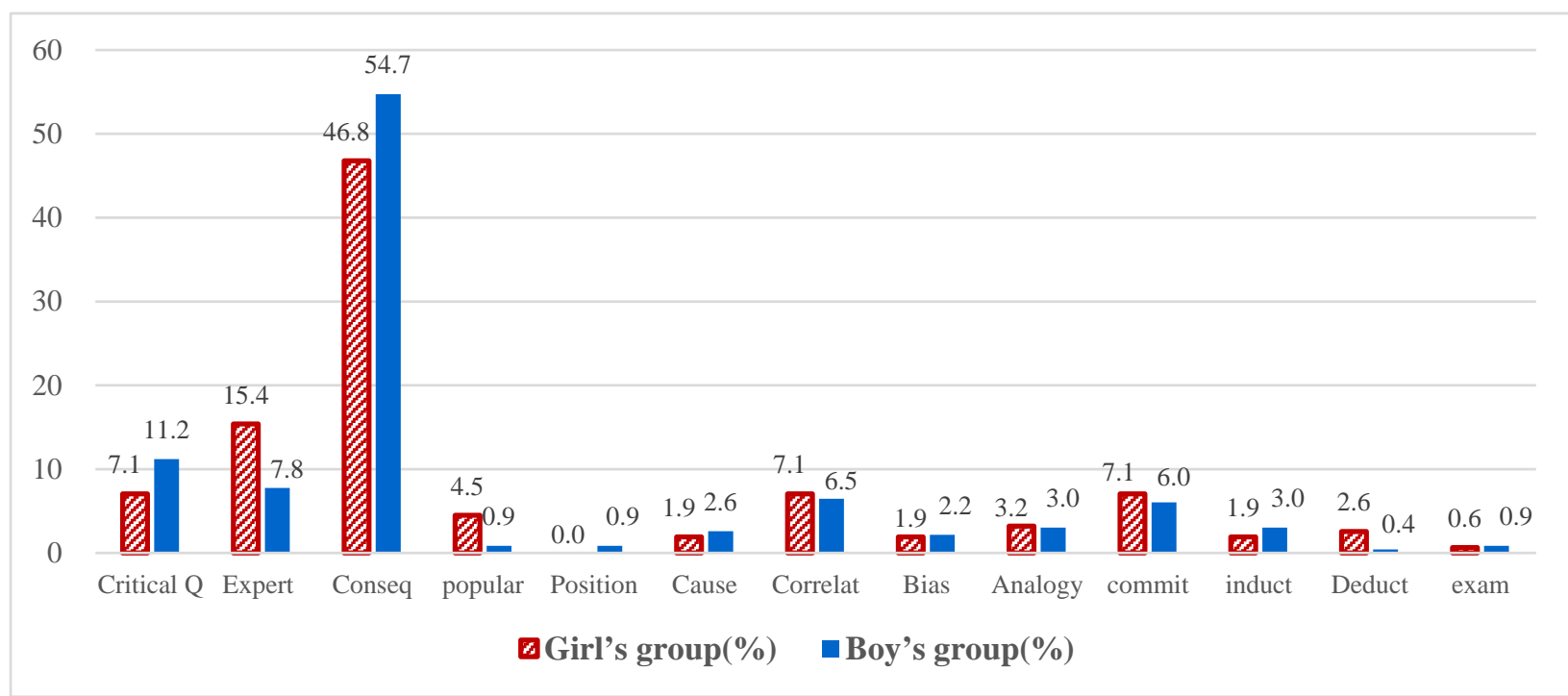

Figure 5. Engineering reasoning of girls and boys in single-gender group discussions

In mixed-gender group discussions, both girls and boys used more 'commitment' type reasoning (See Figure 6) and the frequency of girls' use of 'critical questions' increased, but no notable difference was found between genders. This result shows that students' reasoning in the decisionmaking process is similar between boys and girls, and it is not significantly affected by single- or mixed-gender grouping. 


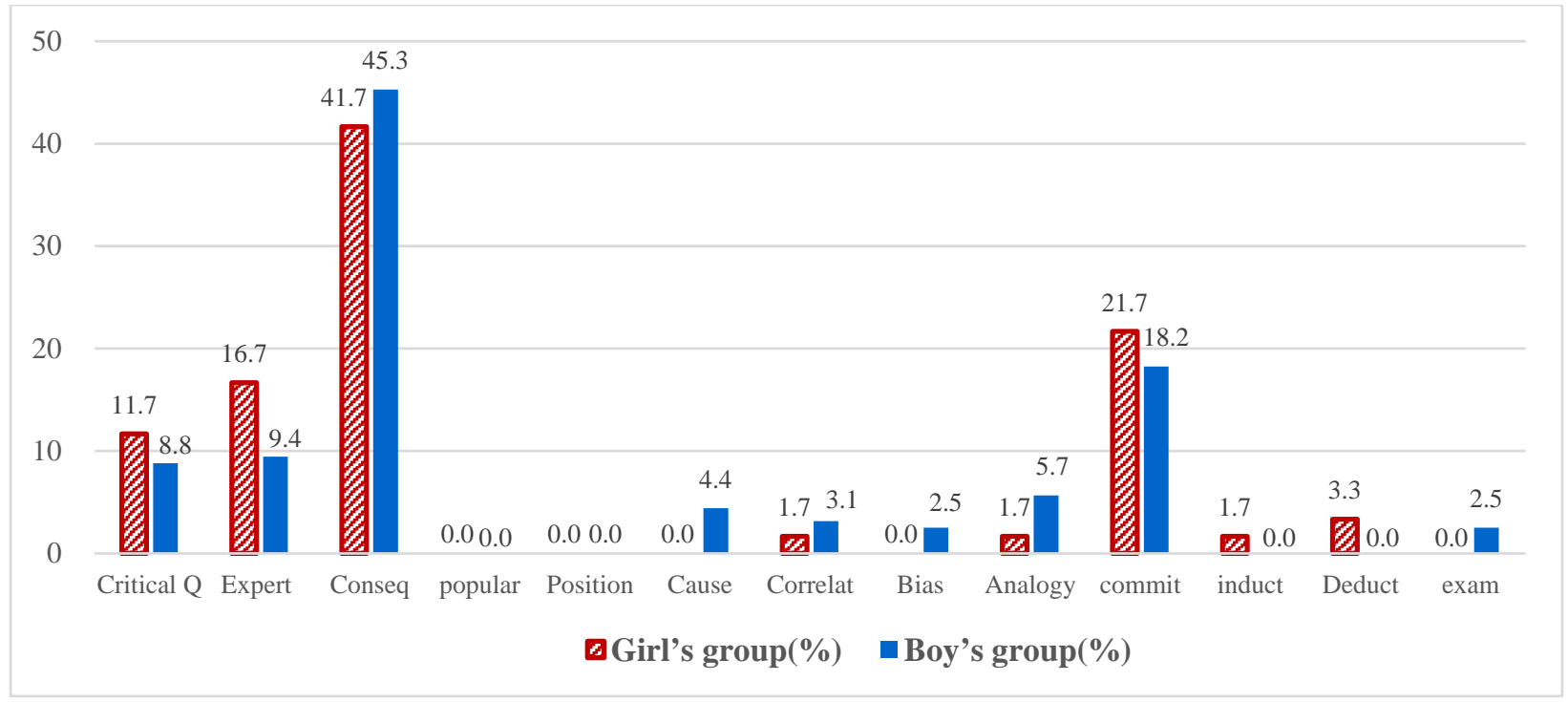

Figure 6. Engineering reasoning of girls and boys in mixed-gender discussions

Critical factors for final decision-making. Along with social negotiation patterns and collaborative reasoning, we also carefully looked at students' discussions as flows of decisionmaking and identified critical factors that affected their final decisions in each unit of discourse analysis. Figures 7-10 present the flow of students' decision-making process of ranking five renewable energy sources for the context of South Korea during the first group discussion (singlegender groups). Critical factors that affected students' decisions of 'selection' (shown in yellow) or 'non-selection' (shown in pink) of renewable energy were described in a box. 


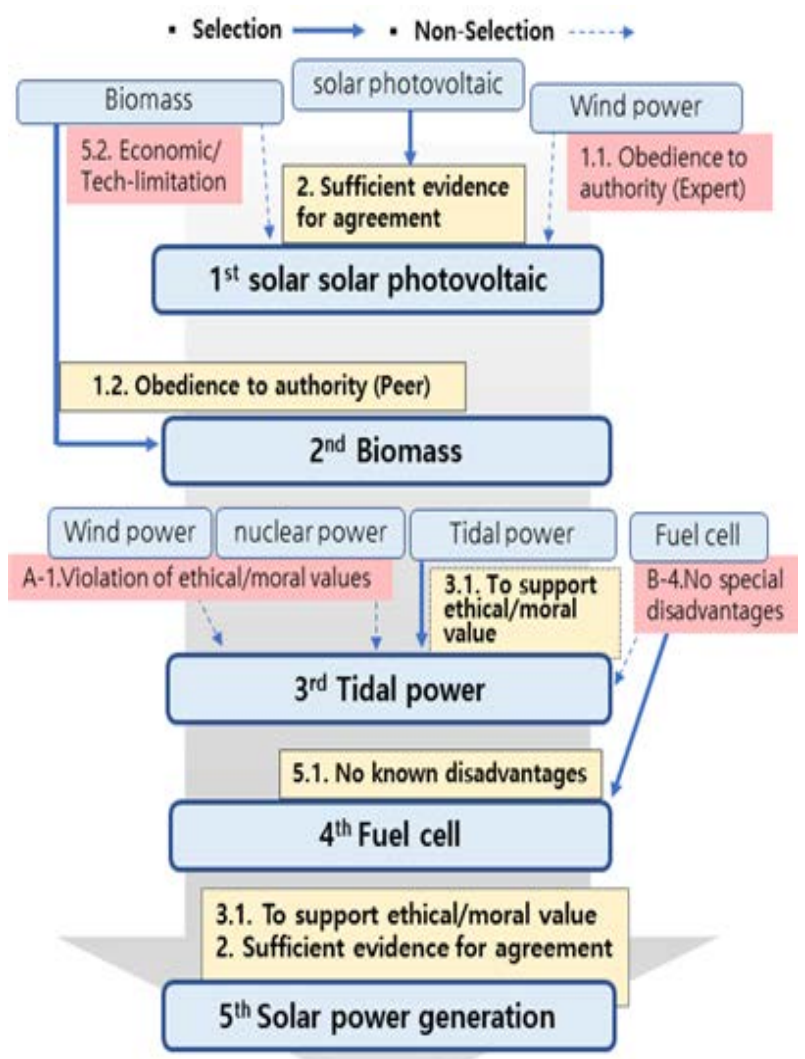

Figure 7. Group 1’s (girls) decision-making process in the first discussion

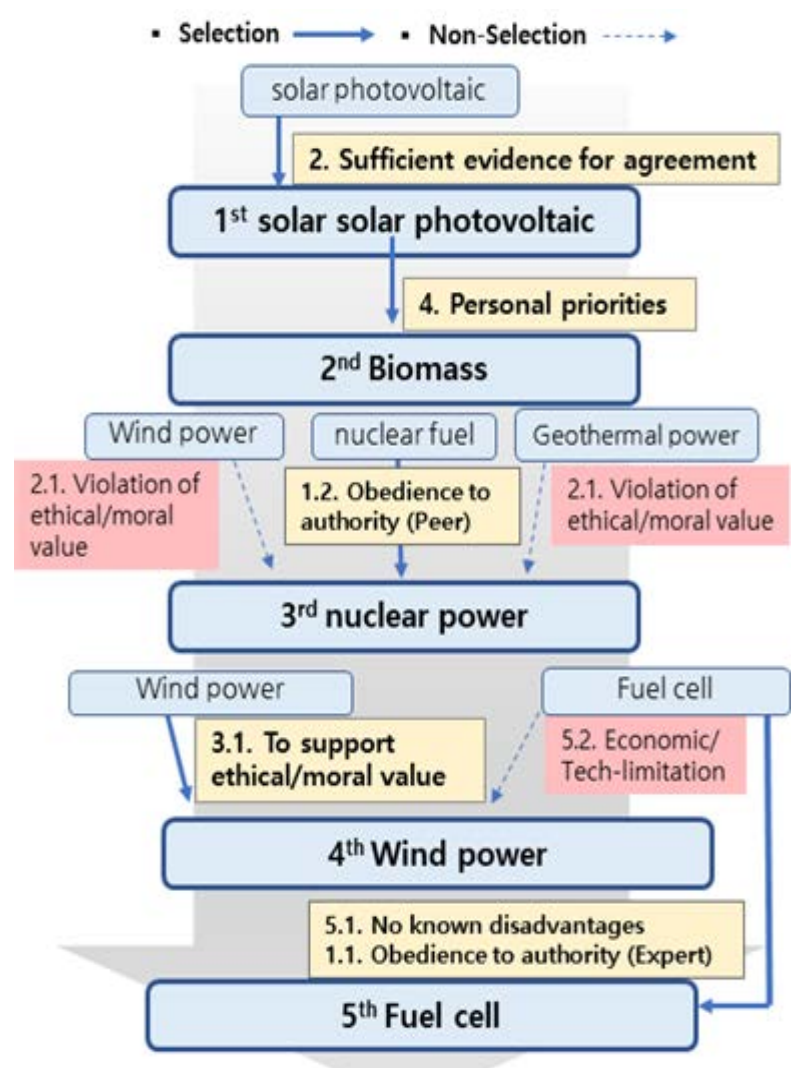

Figure 8. Group 2’s (girls) decision-making process in the first discussion

For example, Figure 7 shows that this group of students selected solar photovoltaic as their top choice because they had sufficient evidence for agreement. They also discussed biomass and wind power as possibilities but ultimately discarded these as their top options because of economic disadvantages or technological limitations for biomass or out of obedience to expert authority for wind power. After the first decision, priority was given to biomass over wind power by simply accepting a peer's knowledge. Because the information teacher (expert) gave about the disadvantages of wind power (repulsion of local people by noise), they did not consider wind power for the option. They chose tidal power as their third choice because it did not violate ethical values. They only considered ethical value for their decision even if there was another option of fuel cells. After their selection of tidal power, they simply accepted fuel cells because there were no known disadvantages. Solar power generation was selected for their final choice because it was similar to photovoltaic in many ways: environmentally friendly and no known disadvantages. 


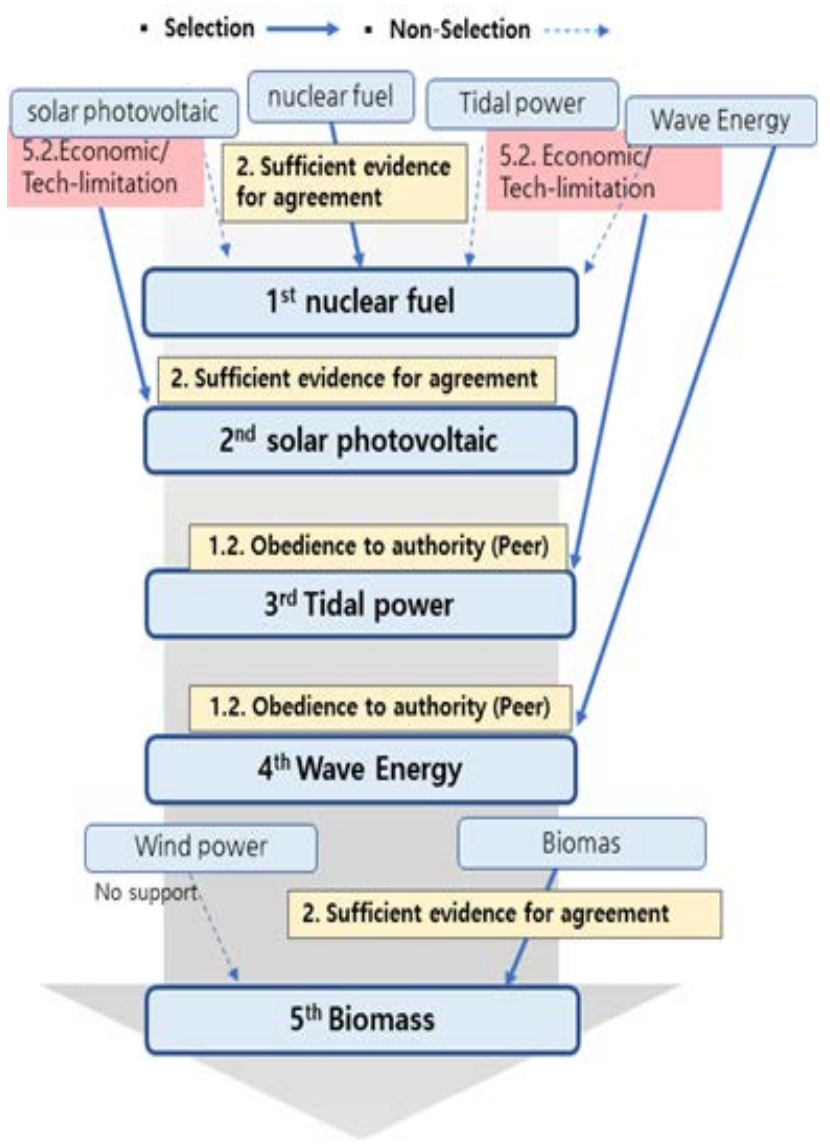

Figure 9. Group 3’s (boys) decision-making process in the first discussion

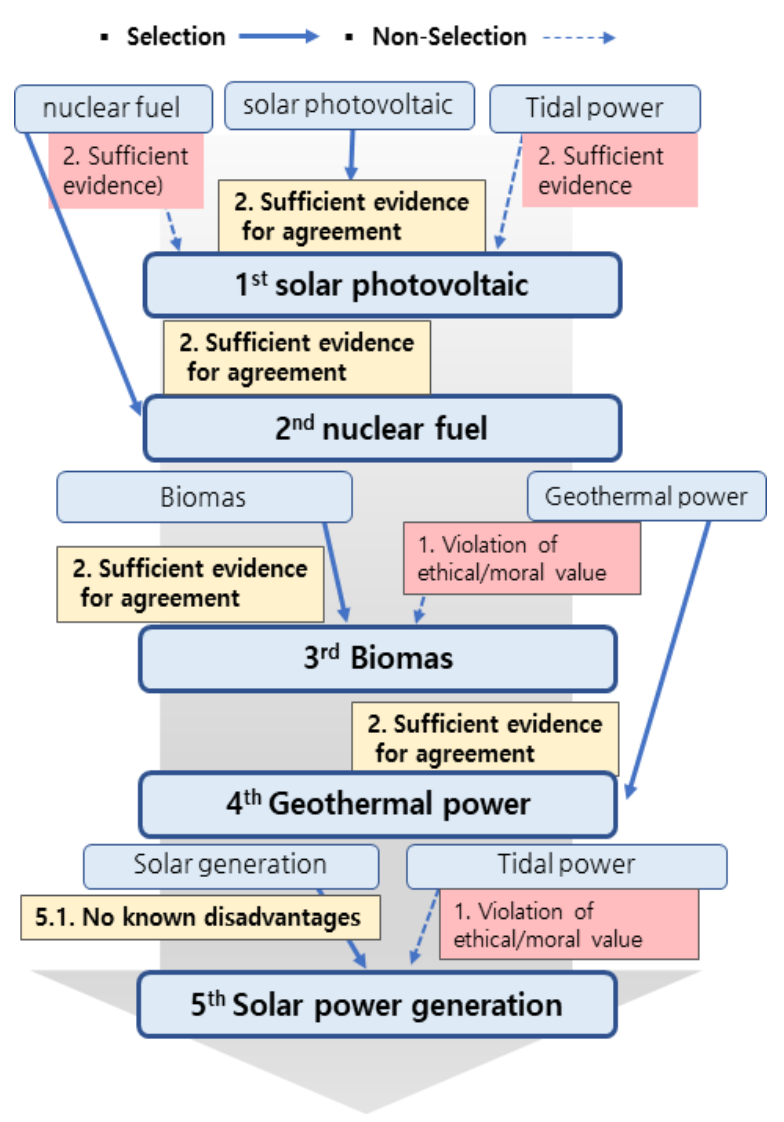

Figure 10. Group 4's (boys) decision-making process in the first discussion

Table 6 presents the frequency of critical factors for students' selection or non-selection of a renewable energy source over others.

Table 6. Critical Factors for Decision-Making in the First and Fourth Discussion

\begin{tabular}{|c|c|c|c|c|c|c|c|c|c|c|c|c|}
\hline \multicolumn{2}{|c|}{ Discussion (D) } & $\begin{array}{c}\text { First } \\
\text { D }\end{array}$ & $\begin{array}{c}\text { Final } \\
\text { D }\end{array}$ & $\begin{array}{l}\text { First } \\
\text { D }\end{array}$ & $\begin{array}{c}\text { Final } \\
\text { D }\end{array}$ & \multirow{2}{*}{ Girl } & $\begin{array}{l}\text { First } \\
\text { D }\end{array}$ & $\begin{array}{c}\text { Final } \\
\text { D }\end{array}$ & $\begin{array}{l}\text { First } \\
\text { D }\end{array}$ & $\begin{array}{c}\text { Final } \\
\text { D }\end{array}$ & \multirow{2}{*}{ Boy } & \\
\hline & $\operatorname{lect}(S) \&$ & \multicolumn{2}{|c|}{ Group1 } & \multicolumn{2}{|c|}{ Group2 } & & \multicolumn{2}{|c|}{ Group3 } & \multicolumn{2}{|c|}{ Group4 } & & Boy \\
\hline \multicolumn{2}{|c|}{$\begin{array}{l}\text { Factors for } \\
\text { Decision-Making }\end{array}$} & $\begin{array}{c}\mathrm{S} \\
(\mathrm{N} . \mathrm{S})\end{array}$ & $\begin{array}{c}\mathrm{S} \\
(\mathrm{N} . \mathrm{S})\end{array}$ & $\begin{array}{c}\mathrm{S} \\
(\mathrm{N} . \mathrm{S})\end{array}$ & $\begin{array}{c}\mathrm{S} \\
(\mathrm{N} . \mathrm{S})\end{array}$ & $\begin{array}{l}\text { Total } \\
(\%)\end{array}$ & $\begin{array}{c}\mathrm{S} \\
(\mathrm{N} . \mathrm{S})\end{array}$ & $\begin{array}{c}\mathrm{S} \\
(\mathrm{N} . \mathrm{S})\end{array}$ & $\begin{array}{c}\mathrm{S} \\
(\mathrm{N} . \mathrm{S})\end{array}$ & $\begin{array}{c}\mathrm{S} \\
(\mathrm{N} . \mathrm{S})\end{array}$ & $\begin{array}{l}\text { Total } \\
(\%)\end{array}$ & $\begin{array}{l}\text { Total } \\
(\%)\end{array}$ \\
\hline \multirow{2}{*}{$\begin{array}{l}1 . \\
\text { Obedience } \\
\text { to } \\
\text { authority }\end{array}$} & 1.1. (Expert) & (1) & (1) & 1 & & $\begin{array}{c}3 \\
(9.4)\end{array}$ & & & & & 0 & $\begin{array}{c}3 \\
(4.5)\end{array}$ \\
\hline & 1.2. (Peer) & & 1 & 1 & 4 & $\begin{array}{c}6 \\
(18.8)\end{array}$ & $2(2)$ & 3 & & 3 & $\begin{array}{c}10 \\
(29.4)\end{array}$ & $\begin{array}{c}16 \\
(24.2)\end{array}$ \\
\hline
\end{tabular}




\begin{tabular}{|c|c|c|c|c|c|c|c|c|c|c|c|c|}
\hline \multicolumn{2}{|c|}{$\begin{array}{l}\text { 2. Sufficient evidence for } \\
\text { agreement }\end{array}$} & 1 & 1 & 1 & 1 & $\begin{array}{c}4 \\
(12.5)\end{array}$ & 3 & 2 & 4 & 1 & $\begin{array}{c}10 \\
(29.4)\end{array}$ & $\begin{array}{c}14 \\
(21.2)\end{array}$ \\
\hline \multirow{2}{*}{$\begin{array}{l}\text { 3. Moral/ } \\
\text { Ethical } \\
\text { value }\end{array}$} & $\begin{array}{l}\text { 3.1. Violation } \\
\text { of } \mathrm{M} / \mathrm{E} \text { value }\end{array}$ & (1) & (1) & (2) & & $\begin{array}{c}4 \\
(12.5)\end{array}$ & & (1) & (2) & & $\begin{array}{c}3 \\
(8.8)\end{array}$ & $\begin{array}{c}7 \\
(10.6)\end{array}$ \\
\hline & $\begin{array}{l}\text { 3.1. To support } \\
\mathrm{M} / \mathrm{E} \text { value }\end{array}$ & 2 & & 1 & & $\begin{array}{c}3 \\
(9.4)\end{array}$ & & & & 1 & $\begin{array}{c}1 \\
(2.9)\end{array}$ & $\begin{array}{c}4 \\
(6.1)\end{array}$ \\
\hline \multicolumn{2}{|c|}{ 4. Personal priorities. } & & 1 & 1 & & $\begin{array}{c}2 \\
(6.3)\end{array}$ & & & & & $\begin{array}{c}1 \\
(2.9)\end{array}$ & $\begin{array}{c}3 \\
(4.5)\end{array}$ \\
\hline \multirow{2}{*}{$\begin{array}{l}5 . \\
\text { Disadvan- } \\
\text { tages }\end{array}$} & $\begin{array}{l}\text { 5.1. No known } \\
\text { disadvantages }\end{array}$ & $1(1)$ & 3 & 1 & & $\begin{array}{c}6 \\
(18.8)\end{array}$ & & & 1 & & $\begin{array}{c}1 \\
(2.9)\end{array}$ & $\begin{array}{c}7 \\
(10.6)\end{array}$ \\
\hline & $\begin{array}{l}\text { 5.2. Critical } \\
\text { Economic } \\
\text { disadvantages/ } \\
\text { Technological } \\
\text { limitation }\end{array}$ & (1) & (1) & (1) & (1) & $\begin{array}{c}4 \\
(12.5)\end{array}$ & (2) & (3) & (1) & (2) & $\begin{array}{c}8 \\
(23.5)\end{array}$ & $\begin{array}{c}12 \\
(18.2)\end{array}$ \\
\hline \multicolumn{2}{|c|}{ Total } & 8 & 9 & 9 & 6 & $\begin{array}{c}32 \\
(100)\end{array}$ & 9 & 9 & 8 & 7 & $\begin{array}{c}34 \\
(100)\end{array}$ & $\begin{array}{c}66 \\
(100)\end{array}$ \\
\hline
\end{tabular}

Three critical factors were more dominant than other factors: Obedience to authority - Peer (24.2\%), Sufficient evidence for agreement (21.2\%), and Economics/scientific disadvantages (18.2\%). Particularly, the factors, 'Obedience to authority - Peer' (24.2\%) affect both girls' and boys' group. This means both group of students decided to select a renewable energy source based on a peer's claim (when they trusted the peer's science knowledge) even if they did not have enough evidence to support the benefit of selecting it.

'No known disadvantages' (18.8\%) affected girls' final decisions more than boys' final decision. This means that girls decided to select one renewable energy source over others only if they could not find any disadvantage of using it. Even if they had some positive evidence for another option, they considered the other option only if it did not have any disadvantage of using it.

On the other hand, for boys' final decisions, 'Sufficient evidence for agreement' (29.4\%) and 'Obedience to authority - Peer' (24.2\%) had a greater influence than on girls' final decisions. Boys decided to select one renewable energy source over others when they deemed their discussion related to one renewable energy option sufficient to make a collaborative decision. This does not mean that girls did not collect sufficient evidence for agreement; rather it only means that the process of collecting sufficient evidence from peers was critical to reaching an agreement to decide the final choice among boys. Also, 'Critical economic disadvantages/technological limitations' played a critical role for boys’ non-selection of an option. 


\section{Conclusion}

Student's contexts (knowledge, epistemological belief, value, etc) affect their argumentation practices in discussing an engineering-based SSI in a classroom environment. This study started with an assumption that gender could be a critical factor that shapes a student's discourse in SSI environments. Studies about argumentation in SSI show that students' knowledge related to the issue is a critical factor for the quality of student arguments. The students participating in this study were gifted elementary students who enrolled in a gifted science education program in a national university in South Korea. The competitive selection process indicates that there is no significant gender difference in their science knowledge or mathematics skill. The analysis results of their worksheets from the activity in this study also support the idea that there is no significant gender difference in their understanding of the issue. However, the results of this study show that gender differences in engineering-based SSI argumentation exist. By utilizing three different argumentation tools, we unveiled students discourse in three aspects: social negotiation patterns, collaborative reasoning, and critical factors for final decision-making.

First, social negotiation pattern results show that girls' social negotiation was more affected by gender grouping (single- or mixed-gender) than boys' social negotiation. When students worked in single-gender groups, girls talked more than they did in mixed-gender groups, and they used more supportive discourse in communication than boys. This result implies that gender grouping itself could affect the girls’ argumentative practices in the decision-making process.

In collaborative reasoning, there was no significant gender difference. The reasoning scheme of 'Consequences' appeared most frequently in both girls' and boys' group discussions, and the patterns and frequency of other reasoning schemes appearing in both gender groups were similar. The only notable difference between gender in reasoning schemes is that girls use more 'Expert opinion' reasoning than boys. This result shows that students' reasoning in the engineering decision-making process is similar between gender and it is not affected by single- or mixedgender grouping.

Along with social negotiation patterns and collaborative reasoning, we also carefully examined students' discussion as a flow of the decision-making process to identify the critical factors that affected their final decision in each unit of discourse analysis. The results showed that girls' engineering decisions were more safety-oriented, so they prioritized energy options with "no known disadvantages" even if other options had known advantages. In contrast, boys selected an option if they felt that they had collected sufficient evidence to reach consensus and did not select an option if it included economic disadvantages or technological limitations. This result implies that there are gender differences in terms of critical factors that could affect the final decisionmaking of one renewable energy source over another in the context of the engineering-based SSI. 


\section{References}

[1] C. R. Wolfe, “Argumentation across the curriculum,” Written Communication, vol. 28, pp. 193-219, 2011.

[2] National Research Council, A Framework for K-12 Science Education: Practices, Crosscutting Concepts, and Core Ideas. Washington, DC: National Academies Press, 2012.

[3] C. A. Mathis, E. A. Siverling, A. W. Glancy, S. S. Guzey, and T. J. Moore, "Students' use of evidence-based reasoning in K-12 engineering: A case study," in Proceedings from the ASEE Annual Conference \& Exposition, New Orleans, LA. American Society for Engineering Education, 2016.

[4] H. Jho, H. G. Yoon, and M. Kim, "The relationship of science knowledge, attitude and decision making on socio-scientific issues: The case study of students' debates on a nuclear power plant in Korea," Science \& Education, vol. 23, pp. 1131-1151, 2014.

[5] R. Khishfe, "Explicit nature of science and argumentation instruction in the context of socioscientific issues: An effect on student learning and transfer," International Journal of Science Education, vol. 36, pp. 974-1016, 2014.

[6] T. D. Sadler, "Informal reasoning regarding socioscientific issues: A critical review of research," Journal of Research in Science Teaching, vol. 41, pp. 513-536, 2004.

[7] Y.-T. Wu and C.-C. Tsai, "High school students' informal reasoning regarding a socio-scientific issue, with relation to scientific epistemological beliefs and cognitive structures,” International Journal of Science Education, vol. 33, pp. 371-400, 2010.

[8] B. Steffen and C. Hößle, "Decision-making competence in biology education: Implementation into German curricula in relation to international approaches," Eurasia Journal of Mathematic s, Science \& Technology Education, vol. 10, pp. 343-355, 2014.

[9] M. Means and J.-F. Voss, "Who reasons well? Two studies of informal reasoning among students of different grade, ability, and knowledge levels," Cognition and Instruction, vol. 14, pp. 139-178, 1996.

[10] R. Duschl, "Quality argumentation and epistemic criteria," in Argumentation in Science Education, S. Erduran and M. P. Jiménez-Aleixandre, Eds. Dordrecht, The Netherlands: Springer, 2008, pp. 159-175. 
[11] S. Ryu and W. A. Sandoval, "Improvements to elementary children's epistemic understanding from sustained argumentation,” Science Education, vol. 96, pp. 488-526, 2012.

[12] S. Ryu and W. A. Sandoval, "The influence of group dynamics on collaborative scientific argumentation," Eurasia Journal of Mathematics, Science and Technology Education, vol. 11, pp. 335-351, 2015.

[13] T. D. Sadler and L. A. Donnelly, "Socioscientific argumentation: The effects of content knowledge and morality," International Journal of Science Education, vol. 28, pp. 14631488, 2006.

[14] Toulmin, S. E. The Uses of Argument. London: Cambridge University Press, 1958.

[15] E. M. Nussbaum, "Argumentation, dialogue theory, and probability modeling: Alternative frameworks for argumentation research in education,” Educational Psychologist, vol. 46, pp. 84-106, 2011.

[16] C. Plantin, L'argumentation: Histoire, Théories, et Perspectives. France: Presses Universitaires, 2005.

[17] D. N. Walton, Argumentation Schemes for Presumptive Reasoning. Mahwah, NJ: Lawrence Erlbaum, 1996.

[18] D. H. Jonassen and B. Kim, “Arguing to learn and learning to argue: Design justifications and guidelines,” Educational Technology Research and Development, vol. 58, pp. 439457, 2010.

[19] W. A. Sandoval and K. A. Millwood, "What can argumentation tell us about epistemology?” in Argumentation in Science Education, S. Erduran and M. P. JiménezAleixandre, Eds. Dordrecht, The Netherlands: Springer, 2008, pp. 71-88.

[20] M. G. Jones et al., “Tool time: Gender and students' use of tools, control, and authority,” Journal of Research in Science Teaching, vol. 37, pp. 760-783, 2000.

[21] J. E. Lansford and J. G. Parker, “Children's interactions in triads: Behavioral profiles and effects of gender and patterns of friendships among members, Developmental Psychology, vol. 35, p. 80, 1999.

[22] B. Thorne, Gender Play: Girls and Boys in School. New Brunswick, NJ: Rutgers University 
Press, 1993.

[23] N. Dasgupta, M. M. Scircle, and M. Hunsinger, "Female peers in small work groups enhance women's motivation, verbal participation, and career aspirations in engineering," Proceedings of the National Academy of Sciences of the United States of America, vol. 112, pp. 4988-4993, 2015.

[24] V. Savicki and M. Kelley, "Computer mediated communication: Gender and group composition,” CyberPsychology \& Behavior, vol. 3, pp. 817-826, 2000.

[25] K. Hawkins and C. B. Powers, "Gender differences in questions asked during small decision-making group discussions,” Small Group Research, vol. 30, pp. 235-256, 1999.

[26] S. B. Merriam, Qualitative Research and Case Study Applications in Education (2nd ed.). San Francisco, CA: Jossey-Bass Publishers, 1998.

[27] R. Lesh, M. Hoover, B. Hole, A. Kelly, and T. Post, "Principles for developing thought-revealing activities for students and teachers," in Handbook of Research Design in Mathematics and Science Education, A. E. Kelly and R. A. Lesh, Eds. Mahwah, NJ: Lawrence Erlbaum, 2000, pp. 591-646.

[28] Nam, Y., \& Chen, Y. C. (2017). Promoting argumentative practice in socio-scientific issues through a science inquiry activity. EURASIA Journal of Mathematics, Science and Technology Education, 13(7), 3431-3461.Authors, 2017.

[29] A. Strauss and J. M. Corbin, Basics of Qualitative Research: Grounded Theory Procedures and Techniques. Newbury Park, CA: Sage Publications, 1990.

[30] M. D. LeCompte and J. Preissle, Ethnography and Qualitative Design in Educational Research (2nd ed.). New York, NY: Academic Press, 1993.

[31] Y.-C. Chen, B. Hand, and S. Park, "Examining elementary students' development of oral and written argumentation practices through argument-based inquiry," Science and Education, vol. 25, pp. 277-320, 2016.

[32] S. Kim and B. Hand, "An analysis of argumentation discourse patterns in elementary teachers' science classroom discussions," Journal of Science Teacher Education, vol. 26, pp. 221-236, 2015.

[33] F. Macagno and A. Konstantinidou, “What students' arguments can tell us: Using 
argumentation schemes in science education,” Argumentation, vol. 27, pp. 225-243, 2013. 